\title{
A Brief Theoretical View on PAD-based Instruction in English Language Learning Amongst Chinese College Students
}

\author{
Huanan Su \\ Universiti Pendidikan Sultan Idris, Perak, Malaysia
}

\begin{abstract}
This article gives a brief theoretical view on the implementation of PAD-based instruction in Chinese college students' English language learning. The article first introduces the situation of English language learning in the present China, especially the learning amongst Chinese college students. And then it informs the readers of the rise of PAD-based instruction, including the three phases of PAD-based instruction in English language learning. Finally, the article focuses on a theoretical view on PAD-based instruction, including the view of the social constructivist theory, the view of the collaborative learning theory and the view of the sociocultural theory. A brief theoretical view on PAD-based instruction in the article will help readers understand how the theories are fundamentally employed to carry out the procedures of PAD-based instruction in English language learning amongst Chinese college students.

Keywords: PAD-based Instruction; English Language Learning; Chinese College Students; A Theoretical View

About the Author: Su Huanan, male, born on 1987-08-03, from Puning city, Guangdong province, is a university lecturer in China. His interest is Teaching of English as a Second or Foreign Language (TESL/TEFL).
\end{abstract}

DOI: $10.36012 /$ fhe.v 1 i1 1.892

\section{Introduction}

$\mathrm{T}$ he first two decades of the 21st century have seen a rapidly growing economy of China, along with which English language learning has also caught on an unprecedented situation covering every section in China. The English language learning has begun to develop both through public education system and private English teaching organizations or institutions (Yu, 2019). A good command of English is considered as a significant skill in China for an individual to advance socially, politically, economically and culturally (Wang, 2018).

\section{English Language Learning Amongst Chinese College Students}

Since China initiated the policy of reform and opening-up in 1978, its economy has been developing at a fast pace. English language learning began to play an increasingly important role in China's education, es- pecially amongst Chinese college students, in bid to respond to the needs of its rapid economic development, further enhance international cooperation as well as strengthen China's economic competitiveness in the world. After large amounts of study and research, the English education curriculum has been reformed, new textbooks have been developed, and professional trainings for teachers have been correspondingly upgraded (Alshammari, 2017). There has also been, as is mentioned above, a widespread of English language learning amongst Chinese college students, allowing different regions of China to have more and gradual access to the basic English language learning resources.

Besides, the advent of the age of information and technology has brought enormous changes to the contemporary world $(\mathrm{Hu}, 2011)$. The appeal of the Internet to Chinese college students' learning nowadays has never been greater (Cao \& Fu, 2016). With the 
help of the digital technology, more and more Chinese scholars, educators and teachers from the tertiary level are examining how well the ever better teaching methodology can make differences to the English language learning amongst college students.

\section{PAD-Based Instruction}

Relating to the above-mentioned situation, Zhang Xuexin, a professor from the Department of Psychology, Fudan University of China, employs a series of theories as the fundamental basis and proposes a new teaching method, PAD-based instruction (Zhang, 2014), which refers to the Presentation-Assimilation-Discussion-based instruction. Based on the theory of the social constructivism and the concept of collaborative learning, PAD-based instruction integrates in-class learning with out-of-class learning, playing a comprehensive role in English language learning amongst Chinese college students.

In general, PAD-based instruction refers to an integration of three phases: knowledge presentation, students' independent assimilation, and interactive group discussion. Teachers' teaching plays a helpful and promoting role in students' learning through all the phases.

To illustrate, in the first phase, namely, the knowledge presentation phase, or the in-class lectures, the principle of the PAD-based instruction lies in the introductory knowledge presentation and instructive thinking (Zhang, 2014). In this phase, only half of the classroom time will be used by the teacher, and there will be neither interactions nor discussions.

In the second phase of the PAD-based instruction, namely, the students' independent assimilation phase, it gives students a certain amount of time after class to read textbooks, complete the homework, understand in depth in their own way and personalize the knowledge presented in the first phase. This phase requires students to use whatever means they can make use of to complete everything independently, but cannot discuss or communicate with classmates or teachers.

In the third phase, namely, the interactive group discussion phase, group discussion, spot checks by the teacher, free questions and teacher summary are included. The in-class discussion is usually made up of groups of four students, with the time for discussion ranging from 5 to 20 minutes. This phase requires students to cooperate with their group members, to inter- act with and learn from each other, and to solve problems together. For problems that cannot be solved within groups, they will be solved through the whole class in the teacher summary (Zhang, 2017).

\section{A Brief Theoretical View on PAD-Based Instruction}

A brief theoretical view on PAD-based instruction will help readers understand how the theories are basically and logically organized and employed to make up the implementation of PAD-based instruction in the Chinese college students' English language learning. In general, the social constructivist theory is fundamentally appropriate for guiding this teaching method because the problems must be understood in a combination of historical, socioeconomic, and cultural contexts (Lodico, Spaulding, \& Voegtle, 2010). The social constructivist approach to learning builds meaning and sense from experiences (Merriam, Caffarella, \& Baumgartner, 2007). To illustrate, a brief theoretical view on PAD-based instruction includes a view of the social constructivist theory (Bruner, 1966), a view of the collaborative learning theory (Johnson \& Johnson, 1987) and a view of the sociocultural theory (Vygotsky, 1978).

\subsection{A View of the Social Constructivist Theory}

The social constructivist theory has been developed from the theories of Bruner (1966) and Vygotsky (1978). According to the theories, knowledge is not a fixed object; rather, it is fluid. College students get knowledge through engagements in inter-collaborative learning activities with other college students with the instructors and the language learning environment. The social constructivist approach to language learning puts emphasis on authentic, challenging projects that include college students, college teachers, and even experts in the language learning environment with the goal of creating language teaching communities that are more closely related to the cooperative practice in the physical world (Bruner, 1966).

Thus, in an authentic environment, college students assume the responsibilities of their own language learning in which they have to develop the meta-cognitive abilities to navigate their independent and autonomous learning and control their personal language performance. What is learned and constructed depends both on the cooperative learning and shared experiences in the students' group discussion. College stu- 
dents' knowledge can also be socially constructed and reconstructed through dialogue-based communication, text-based interaction, technology-based understanding, and face-to-face discussions.

In the context of an English language learning situation, the implementation process of PAD-based instruction has fully shown great compliance with the social constructivist theory. In the first session of the teaching process, the teacher acts as the founder of the learning "situation" and helps the students to complete the construction of meaning. In the second session of the knowledge internalization absorption process, students become the active constructors of knowledge, personalize the absorption, and complete the tasks independently. In the third session of group discussion, the students complete the "collaboration" and "conversation", finally reaching the "meaning construction".

\subsection{A View of the Collaborative Learning Theory}

The Collaborative Learning Theory (CLT) was first developed from the scholarly work of Bruffee (1984, 1987) as well as Johnson and Johnson (1987). It mainly focuses on group interaction as a very important factor of cooperative learning that regards sharing as a fundamental feature of successful cooperation. Sharing is a very broad concept which includes but not limited to sharing information about language learning, language insights, and personal experiences, and perspectives (Bruffee, 1995). According to Bruffee (1995), the more insights and viewpoints are shared by college students, the better opportunities are created for engaging minds in a network of thoughts that lead to more negotiations and multiple perspectives. This will directly empower language learning and make the process of language learning more authentic.

In a setting of collaborative learning, college students do not learn passively but instead actively negotiate and discover more meaning through re-conceptualization of prior knowledge and through working in an environment that reduces anxiety and uncertainty. PAD-based instruction encourages college students' collaborative learning, especially when the college students are required to present what they have discussed in their group discussion. At the same time, college students in the setting of collaborative learning are motivated to learn with group members, because they feel that the encouraging words they get from their peers are motivational rewards. In that case, within the context of group discussion, college students develop a positive attitude towards the concept of cooperative language learning and become inter-dependent language learners in their group interaction and discussion when they share information with each other and help each other through inquiry-based learning.

\subsection{A View of the Sociocultural Theory}

The Sociocultural theory (Vygotsky, 1962, 1978) reveals a potential application of collaborative language learning through computer-supported collaborative learning (CSCL) (Miller, 1995), which actually informs the students of the aspect of the potential advantages of technology in their language learning. In the second phase of PAD-based instruction, college students are required to hand on reflective notes during their autonomous learning. In that case, they might tend to apply technology to their social language learning. Vygotsky (1986) has argued that learning is embedded within social events and occurs when a novice college student interacts with people, objects, and events in the learning environment.

In short, an informal and formal learning infused with technology will obviously increase the students' level of participation and interaction within group discussions and even decrease their learning anxiety, which is essentially advocated as a philosophical basis by the PAD-based instruction.

\section{Conclusion}

Theoretical assumptions play a role in implementing a specific teaching methodology. It is thus worth analyzing the theoretical foundations when it comes to carrying out the framework of a certain teaching paradigm. A brief theoretical view on PAD-based instruction highlights a more complicated but logical sequence of the teaching paradigm. Based on the brief theoretical view, readers will be more aware of the philosophical assumptions of PAD-based instruction in English language learning amongst Chinese college learners.

\section{References}

[1] Alshammari B. Teaching English as a Second Language in Saudi Arabia and China.(Unpublished master's dissertation). 2017.

[2] Bruffee K. A. Collaborative learning and the conversation of mankind [J]. College English, 1984, (46): 635-652.

[3] Bruffee K. A. The art of collaborative learning: Making the most of knowledgeable peers [J]. Change, 1987, 19 (2): $42-47$.

[4] Bruffee K.A. Sharing our toys-Cooperative learning versus collaborative Learning [J]. Change, 1995, 27(1): 12-19. 
[5] Bruner J. S. Toward a theory of instruction. Cambridge, Mass: Belknap Press Harvard University. 1966.

[6] Forman E. A., Cazden C. B. Exploring Vygotskian perspectives in education: The cognitive value of peer interaction. In J. V. Wertsch (Ed.), Culture, Communication and Cognition: Vygotskian Perspectives (pp. 323-347). London: Cambridge University Press. 1985.

[7] $\mathrm{Hu} \mathrm{G}$, McKay S. English language education in East Asia: Some recent developments [J]. Journal of Multilingual and Multilingual Development, 2011, (33): 345-362.

[8] $\mathrm{Hu} \mathrm{M}$. A discussion of teaching reform and practice of advanced English under multimedia network environment [J]. Journal of Changshu Institute of Technology (Educational Sciences), 2011, (6): 56-59.

[9] Johnson D. R., Johnson F. P. Joining Together. (10th Ed.). Upper Saddle River, NJ: Prentice Hall. 2010.

[10] Johnson D. W., Johnson R. T. Conflict resolution and peer mediation Programs in elementary and secondary schools: A review of the research [J]. Review of Educational Research, 1987, (66): 459-506.

[11] Lodico M., Spaulding, D., Voegtle, K. Methods in educational research: from theory to practice. San Francisco, CA: Jossey-Bass. 2010.

[12] Merriam S. B., Caffarella R., Baumgartner, L. Learning in adulthood: A comprehensive guide. San Francisco, CA: Jossey-Bass. 2007.

[13] Miller S. M. Vygotsky and education: The Sociocultural genesis of dialogic thinking in classroom contexts for open-forum literature discussions. 1995. http://www. glasnet.ru/ vega/vygodsky/miller.html

[14] Moll L. Teaching second language students: A Vygotskian perspective. In D. M. Johnson, D. H. Roen (Eds.), Richness in writing. New York: Longman. 1989.

[15] Vygotsky L. S. Thought and Language. Cambridge: MIT Press. 1962.

[16] Vygotsky L. S. Mind in society: The development of higher psychological processes. Cambridge, MA: Harvard University Press. 1978.

[17] Vygotsky L. S. Thought and language. Cambridge, MA: The MIT Press. 1986.

[18] Wang J. Exploration and practice of the PAD class based on process assessment in the course of Advanced Mathematics [J]. Journal of University of Shanghai for Science and Technology, 2018, 40(3): 278-282.

[19] $\mathrm{Yu}$ Aiqing. Understanding Information Technology Acceptance and Effectiveness in College Students' English Learning in China. (Unpublished doctoral dissertation). University of Nebraska, Nebraska, America. 2019.

[20] Zhang Xuexing. The PAD Class: A New Exploration in University Classroom Teaching Reform [J]. Fudan Education Forum, 2014, 12(5): 5-10.

[21] Zhang Xuexing. The PAD Class: A New Exploration of University Classroom Teaching. Chinese Science Paper Online. 2015. Retrieved from https://duifen.org/wp-content/ uploads/2015/08/PAD_Class.pdf.pdf

[22] Zhang Xuexing. The PAD Class: The New Wisdom of Chinese Education. Beijing: Science Press. 2016.

[23] Zhang Xuexing. The PAD Class: A new paradigm for university classroom teaching. Proc. SPIE 10452, 14th Conference on Education and Training in Optics and Photonics:ETOP, 2017, 104521X. doi: 10.1117/12.2270967 